\title{
Serotonin transporter mRNA expression in the dorsal raphe nucleus of a tumor bearing mouse
}

\author{
Jeong Won Jahng ${ }^{1}$, Si Ho Choi ${ }^{1}$, \\ Mi Joo Cha ${ }^{1}$, Nam Youl Kim ${ }^{1}$, \\ Soon Jeong Hwang ${ }^{2}$ and Jong-Ho Lee $\mathrm{Le}^{2,3}$ \\ ${ }^{1}$ Department of Pharmacology \\ BK21 Project for Medical Science \\ Yonsei University College of Medicine \\ Seoul 120-752, Korea \\ ${ }^{2}$ Department of Oral and Maxillofacial Surgery \\ Dental Research Institute \\ Seoul National University College of Dentistry \\ Seoul 110-744, Korea \\ ${ }^{3}$ Corresponding author: Tel, 82-2-2072-2630; \\ Fax, 82-2-766-4948; E-mail, leejongh@plaza.snu.ac.kr
}

Accepted 5 January 2005

Abbreviations: DRN, dorsal raphe nucleus; 5-HTT5, hydroxytryptamine reuptake transporter

\begin{abstract}
This study was conducted to determine if an oral squamous cell carcinoma alters mRNA expression of serotonin transporter (5-HTT) in the central nervous system. KB cell line derived from a human oral squamous cell carcinoma was inoculated into nude mice, and mRNA expression level of 5-HTT in the dorsal raphe nucleus (DRN) was examined by in situ hybridization when the tumor mass reached to $-10 \%$ of total body weight. Plasma leptin levels were determined by radioimmunoassay method using a commercial kit. 5-HTT mRNA level was significantly decreased in the DRN of tumor bearing mice, compared to the age-matching non-tumor control. Plasma leptin level decreased concomitantly in tumor bearing mice. These results suggest that oral carcinoma may suppress 5-HTT gene expression in the central nervous system, perhaps in relation with decreased plasma leptin level.
\end{abstract}

Keywords: depression; gene expression; in situ hybridization; leptin; serotonin; tumor

\section{Introduction}

Dysregulation of serotonin (5-hydroxytryptamine, 5-
HT) system is known to play a role in the pathophysiology of depressive disorders (Maes and Meltzer, 1995; Mann, 1999). It has been reported that serum concentrations of tryptophan, 5-HT precursor, are significantly decreased in cancer patients (Brown et al., 1989; 1991), and that this decrease correlates with depressive symptoms in cancer patients undergoing cytokine therapy (Capuron et al., 2002). Depression is one of the major symptoms commonly found in cancer patients, and reported to worsen survival of the patients (Goodwin et al., 2004; Klinkenberg et al., 2004). However, the mechanism by which cancer induces depression in the patients is largely unknown.

5 -HT reuptake transporter (5-HTT) is a member of the $\mathrm{Na}^{+} / \mathrm{Cl}^{-}$-dependent membrane transporters family, controls the propagation of serotonergic signal timely by reuptake of 5 -HT from the synaptic cleft immediately after its release. Pharmacologic inhibition of 5 -HTT with selective 5-HT reuptake inhibitors, such as fluoxetine, enhances serotonergic transmission and decreases depression symptoms (Gorman and Kent, 1999). Gene expression of 5-HTT in the dorsal raphe nucleus (DRN), where the largest population of serotonergic neurons is located, alters by brain 5 - HT level (Linnet et al., 1995; Choi et al., 2003). Decreased expression or lack of 5-HTT appears to correlate with the development of behavioral depression. That is, 5-HTT mRNA expression was decreased in the DRN of ob/ob mouse showing symptoms of behavioral depression (Collin et al., 2000), and the number of 5-HTergic neurons and their neuronal activity was decreased in the DRN of 5-HTT knockout mouse exhibiting behavioral depression (Lira et al., 2003).

5-HTT mRNA level in the DRN has been suggested to correlate with plasma leptin level (Jahng et al., 1998; Collin et al., 2000; Johansen et al., 2000). It has been reported that leptin increases brain 5-HT levels in wild-type and ob/ob mice (Harris et al., 1998; Calapai et al., 1999), and that leptin receptors are localized in 5-HT or 5-HTT containing neurons in the DRN (Collin et al., 2000; Finn et al., 2001; HaySchmidt et al., 2001). In this study, the DRN expression of 5-HTT mRNA and the plasma leptin level were examined in the mice bearing an oral squamous cell carcinoma, in order to define the molecular mechanism of the pathogenesis of depression in cancer subjects.

\section{Materials and Methods}

Anim als

$B A L B / c$ strain male mice at 8 weeks of age were purchased (KRIBB, Taejeon, Korea) and maintained 
in a consistent environment with a $12 \mathrm{~h} / 12 \mathrm{~h}$ lightdark cycle (light between 07:00 and 19:00). Mice received free access to standard laboratory food (Purina Rodent Chow, Purina Co., Seoul, Korea) and water (membrane filtered purified water) ad libitum, and were cared according to The Guide for Animal Experiments, 2000, edited by The Korean Academy of Medical Sciences, which is consistent with $\mathrm{NIH}$ Guideline for the Care and Use of Laboratory Animals, 1996 revised.

\section{Tumor inoculation}

KB cell line, which was derived from a poorly differentiated squamous cell carcinoma in the mouth floor of 54-year-old man, was prepared at a $5 \times 10^{7}$ cells $/ \mathrm{ml}$ concentration. One $\mathrm{ml}$ of the $\mathrm{KB}$ cell culture was subcutaneously inoculated into the dorsal area of mice. The non-tumor control group received $1 \mathrm{ml}$ of saline instead. Tumor weight in grams was estimated by an empirically-derived formula: length $x$ width $\times 1.33 / 100$ (McCarthy and Daun, 1993). Tumor masses were excised at sacrifice, weighed and then processed for $\mathrm{H} / \mathrm{E}$ staining to validate the tumor development in each animal (data not shown).

\section{In situ hybridization}

Tumor bearing mice were sacrificed for 5-HTT in situ hybridization when the tumor mass reached to $-10 \%$ of total body weight $(n=6)$. Age-matching non-tumor mice were processed parallel as the control groups $(n=6)$. Mice were overdosed with sodium pentobarbital (Hallym Pharmaceutical Co., Seoul, Korea) and transcardially perfused first with $100 \mathrm{ml}$ of heparinized isotonic saline containing $0.5 \% \quad \mathrm{NaNO}_{2}$ (Sigma Co., Saint Louis, MO), followed by $100 \mathrm{ml}$ of ice-cold $4 \%$ paraformaldehyde (Sigma Co.) in $0.1 \mathrm{M}$ sodium phosphate buffer. Brains were immediately removed, post-fixed for $2 \mathrm{~h}$, and transferred into $30 \%$ sucrose (Sigma Co.) for cryoprotection. Forty micron coronal sections were cut on a freezing, sliding $\mathrm{mi}-$ crotome (HM440E, Microm Co., Germany). Alternate sections through the rostral-caudal extent of the raphe nucleus (between bregma -7.64 and $-8.80 \mathrm{~mm}$; Paxinos and Watson, 1986) were collected into $20 \mathrm{ml}$ glass scintillation vials containing ice-cold $2 \times$ SSC $(0.3 \mathrm{M} \mathrm{NaCl}, 0.03 \mathrm{M} \mathrm{Na}$ Citrate). in situ hybridization was performed with 5 -HTT cDNA probe (a $0.8 \mathrm{~kb}$ EcoR1 restriction fragment; Jahng et al., 1998) as previously described (Choi et al., 2003).

\section{Plasma leptin level}

Cardiac blood ( $n=12$ ) was collected into the microtubes containing $20 \mathrm{ml}$ of heparin, rapidly after exposing the heart with an overdose of sodium pentobarbital, and centrifuged at $2,000 \mathrm{rpm}$ for $20 \mathrm{~min}$ to separate the plasma. The plasma leptin level was determined by radioimmunoassay method using a commercial kit (Mediagnost mouse/leptin kit, Aspenhaustr, Reutlingen, Germany).

\section{Image analysis and statistics}

Images on the autoradiographic films were digitized with a Zeiss Stemi-2000 stereoscope attached to a Dage-MTI CCD 72 camera and MCID image analysis system (MCID, Imaging Research Inc., Ontario, Canada). Messenger RNA expression level was determined by quantifying the mean relative optical density of pixels with densities of at least 2 S.D. above the mean density of the image background (mRNA pixels). For each section, the mean background value was subtracted from the mean mRNA pixel value. The mRNA pixel values were averaged across 5 sections from each individual mouse and the average mRNA value of each mouse then averaged across all mice within each group. The average mRNA value of the tumor group was then converted to relative value to the control group. All data were analyzed by unpaired $t$-test using StatView software (Abacus, Berkeley, CA).

\section{Results and Discussion}

\section{5-HTT expression}

Tumor mice were sacrificed when the tumor mass reached to $-10 \%$ of total body weight, the raphe nucleus sections of brain tissues were processed for in situ hybridization with 5-HTT cDNA probes. 5-HTT in situ signals on the autoradiographic films of tumor mice appeared to be decreased compared with the age-matching non-tumor mice (Figure 1A). Quantificational analysis of the in situ signals showed a significant $(P<0.05)$ reduction in 5 -HTT mRNA expression level in tumor mice, i.e. $-65 \%$ of non-tumor mice (Figure 1B). It has been reported that gene expression level of 5-HTT in the DRN may positively correlate with the brain 5-HT level (Linnet et al., 1995; Choi et al., 2003), and that the transgenic mouse lacking 5-HTT expression exhibits decreases in the activity and number of serotonergic neurons in the DRN (Lira et al., 2003). These reports together with our result suggest that the brain $5-\mathrm{HT}$ system may be down-regulated in the tumor bearing mouse. Dysregulation in the brain 5-HT system is known to play a role in the pathophysiology of depressive disorders (Maes and Meltzer, 1995; Mann, 1999). Indeed, both obese $(o b / o b)$ mouse, which exhibits decreased expression of 5-HTT in the DRN, and 5-HTT knockout mouse present behavioral depression (Collin et al., 2000; Lira et al., 2003). These reports support the idea that this tumor animal model may present behavioral depression. Depression is one of the major symptoms commonly found in cancer patients, and reported to worsen survival of the patients (Goodwin et al., 2004; Klinkenberg et al., 2004). However, the brain mechanism by which cancer induces depression in the patients is not known. Further studies on the analyses of brain 5-HT level and behavioral depression in this animal model will provide valuable information about the pathogenesis of depression in cancer patients. 
A
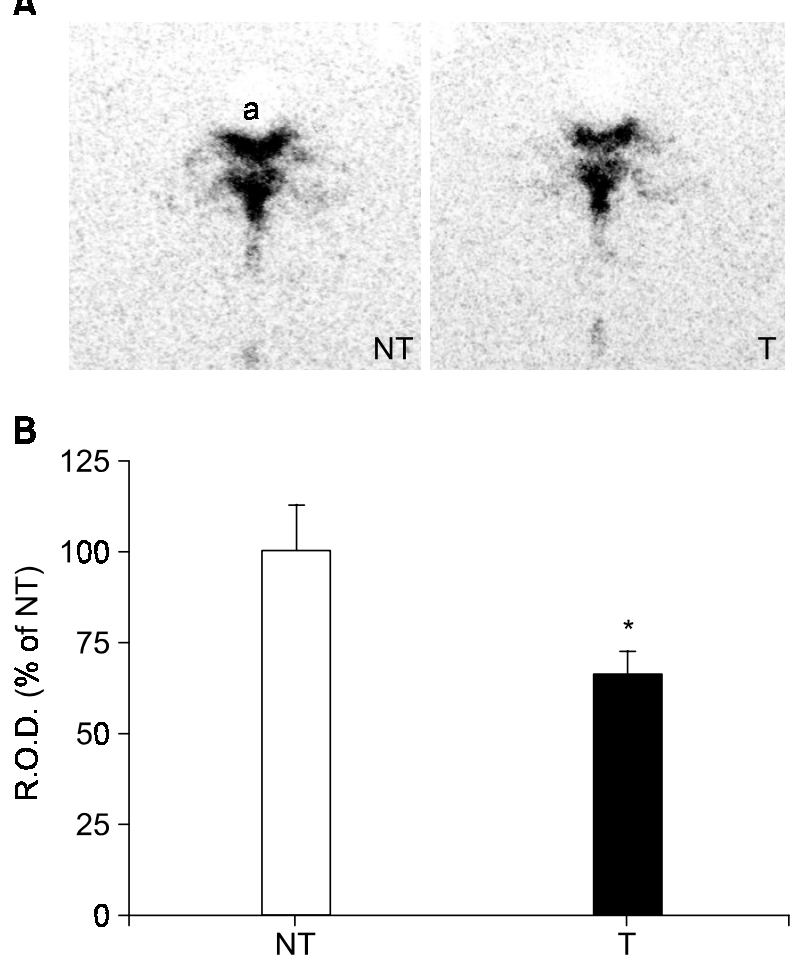

Figure 1. 5-HTT in situ hybridization in the dorsal raphe nucleus (DRN) of mouse bearing a human oral squamous cell carcinoma (T) and the age matching non-tumor control (NT). Mice were sacrificed for in situ hybridization when the tumor mass reached to $-10 \%$ of total body weight. (A) Autoradiography of in situ signals on X-ray films. (B) Relative optical density (R.O.D.) of the in situ signals. 5-HTT mRNA expression was significantly decreased in the DRN of tumor mice, compared to the non-tumor controls. a; acquiduct, ${ }^{*} P<0.05$ vs. non-tumor control.

\section{Plasma leptin and 5-HTT expression}

Plasma leptin levels were analyzed when the tumor ratio reached to $-10 \%$ of total body weight. The plasma leptin levels of tumor mice were markedly decreased $(P<0.05)$ compared with the age-matching non-tumor mice (Figure 2B), concomitantly with the decrease of 5 -HTT mRNA level in the DRN. This result concurs with previous reports that 5-HTT mRNA expression is decreased in ob/ob mouse lacking functional leptin (Collin et al., 2000) and in anorexia (anx/anx) mouse exhibiting decreased level of the plasma leptin (Jahng et al., 1998; Johansen et al., 2000). Leptin increases brain 5-HT levels in wild-type and ob/ob mice (Harris et al., 1998; Calapai et al., 1999) and 5-HT turnover in the brain of wild-type mouse (Calapai et al., 1999). Leptin receptors are localized in the 5-HT (Finn et al., 2001; Hay-Schmidt et al., 2001) or 5-HTT (Collin et al., 2000) containing neurons of the DRN where the most of 5-HT neurons are located in the brain. Leptin which was administrated into the lateral ventricle is accumulated in serotonergic neurons of the raphe nucleus (Fernandez-
A
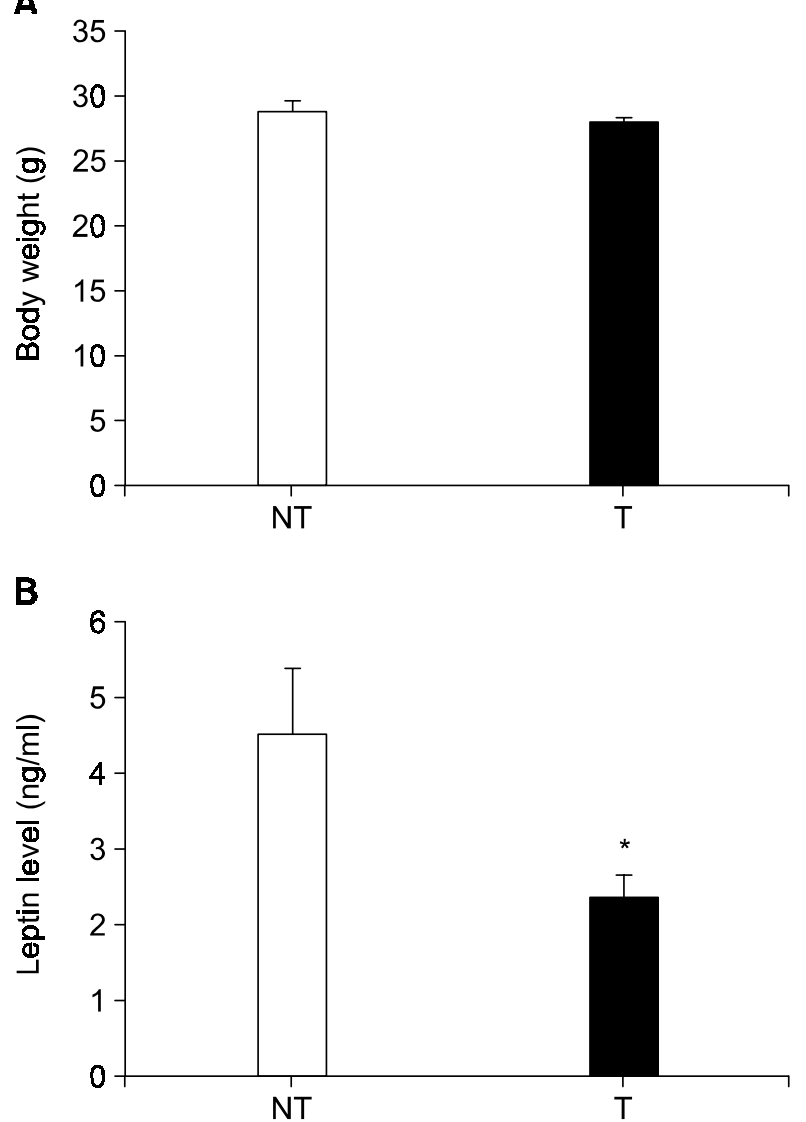

Figure 2. Body weight (A) and plasma leptin level (B). Tumor mice were sacrificed for the plasma leptin assay when the tumor ratio reached to $-10 \%$ of total body weight. Real body weight of the tumor mice (T), which the tumor weight was subtracted from total body weight, was not significantly reduced compared with the non-tumor controls (NT), however, the plasma leptin levels of tumor mice significantly decreased. ${ }^{*} P<0.05$ vs. non-tumor control.

Galaz et al., 2002). Leptin-induced hypophagia, a major behavioral effect of leptin, is inhibited by serotonergic agents, which suppress the brain $5-\mathrm{HT}$ system (Yamada et al., 2003). These reports all suggest that plasma leptin may activate the brain $5-\mathrm{HT}$ system, perhaps through its stimulatory effect on the $5-\mathrm{HT}$ and/or 5-HTT neurons in the DRN. Together with our result, it is suggested that decreased expression of 5-HTT in the DRN of this tumor mouse may be, at least partly, due to a decrease in the plasma leptin level.

\section{Body weight and plasma leptin}

Initial body weight of tumor mice at tumor inoculation did not differ from non-tumor mice $(24.817 \pm 0.359 \mathrm{~g}$ vs. $25.440 \pm 0.432 \mathrm{~g}$ ). Real body weight was calculated by subtracting the tumor weight from total body weight at sacrifice. Real body weight of tumor mice did not significantly differ from the age-matching 
non-tumor mice (Figure 2A). Circulating levels of leptin, a peptide hormone synthesized in adipose tissue, are positively correlated to the body mass index (Maffei et al., 1995). For an example, decreased plasma level of leptin in anorexia mutant (anx/anx) correlates with a significant weight loss compared with its wild type littermates (Jahng et al., 1998). However, in this study the plasma leptin level was significantly decreased in the tumor bearing mouse despite no significant decrease in body weight, compared to the non-tumor control. Leptin release is reported to be regulated by several factors, such as glucocorticoids or insulin stimulates, but catecholamine inhibits its release (Fruhbeck et al., 1998). Further study is required to determine what caused a reduction in plasma leptin level in this tumor mouse model.

In summary, 5-HTT expression was decreased in the DRN of mouse bearing a human oral squamous cell carcinoma. This decrease may correlate with a reduction in the plasma leptin level in this mouse model. This is the first report demonstrating that oral carcinoma may decrease 5-HTT gene expression in the central nervous system. This animal model can be used for future studies on the pathogenesis of depression in cancer subjects.

\section{Acknowledgement}

This work was supported by the Korea Health $21 \mathrm{R}$ \&D Project (03-PJ1-PG3-20500-0025, JHL), the Neurobiology Research Program from the Korea Ministry of Science and Technology (JWJ). MJ Cha and NY Kim received scholarship support from Brain Korea 21 Project for Medical Science.

\section{References}

Brown RR, Lee MC, Kohler PC, Hank JA, Storer BE, Sondel $\mathrm{PM}$. Altered tryptophan and neopterin metabolism in cancer patients treated with recombinant interleukin-2. Cancer Res 1989;49:4941-4

Brown RR, Ozaki Y, Datta SP, Borden EC, Sondel PM, Malone DG. Implications of interferon-induced tryptophan catabolism in cancer, auto-immune diseases and AIDS. Adv Exp Med Biol 1991;294:425-35

Calapai G, Corica F, Corsonello A, Sautebin L, Di Rosa M, Campo GM, Buemi M, Mauro VN, Caputi AP. Leptin increases serotonin turnover by inhibition of brain nitric oxide synthesis. J Clin Invest 1999;104:975-82

Capuron L, Ravaud A, Neveu PJ, Miller AH, Maes M, Dantzer R. Association between decreased serum tryptophan concentraions and depressive synptoms in cancer patients undergoing cytokine therapy. Mol Psychiatry 2002;7:468-73

Choi SH, Kwon BS, Lee S, Houpt TA, Lee HT, Kim DG, Jahng JW. Systemic 5-hydroxy-L-tryptophan down-regulates the arcuate CART mRNA level in rats. Regul Pept 2003;115: $73-80$

Collin M, Hakansson-Ovesjo M-L, Misane I, Ogren SO,
Meister B. Decreased 5-HT transporter mRNA in neurons of the dorsal raphe nucleus and behavioral depression in the obese leptin-deficient ob/ob mouse. Mol Brain Res 2000;81: 51-61

Fernandez-Galaz MC, Diano S, Horvath TL, Garcia-Segura LM. Leptin uptake by serotonergic neurons of the dorsal raphe. J. Neuroendocrinol. 2002;14:429-34

Finn PD, Cunningham MJ, Richard DG, Clifton DK, Steiner RA. Serotonergic neurons are targets for leptin in the monkey. J Clin Endocrinol Metab 2001;86:422-6

Fruhbeck G, Jebb SA, Prentice AM. Leptin: physiology and pathophysiology. Clin Physiol 1998;18:399-419

Goodwin JS, Zhang DD, Ostir GV. Effect of depression on diagnosis, treatment, and survival of older women with breast cancer. J Am Geriatr Sol 2004;52:106-11

Gorman JM, Kent JM. SSRIs and SMRIs: Broad spectrum of efficacy beyond major depression. J Clin Psychiatry 1999; $60: 33-8$

Harris RB, Zhou J, Redmann SM Jr, Smagin GN, Smith SR, Rodgers $E$, Zachwieja JJ. A leptin dose-response study in obese (ob/ob) and lean (+/?) mice. Endocrinology 1998;139: 8-19

Hay-Schmidt A, Helboe L, Larsen PJ. Leptin receptor immunoreactivity is present in ascending serotonergic and catecholaminergic neurons of the rat. Neuroendocrinology $2001 ; 73: 215-26$

Jahng JW, Houpt TA, Joh TH, Son JH. Differential expression of monoamine oxidase $A$, serotonin transporter, tyrosine hydroxylase and norepinephrine transporter mRNA by anorexia mutation and food deprivation. Dev Brain Res 1998; 107:241-6

Johansen JE, Broberger C, Lavebratt C, Johansson C, Kuhar MJ, Hokfelt T, Schalling M. Hypothalamic CART and serum leptin levels are reduced in the anorectic (anx/anx) mouse. Mol Brain Res 2000;84:97-105

Klinkenberg M, Willems DL, Wal G, Deeg DJ. Symptom burden in the last week of life. J Pain Symptom Manage 2004;27:5-13

Linnet K, Koed K, Wiborg O, Gregersen N. Serotonin depletion decreases serotonin transporter mRNA levels in rat brain. Brain Res 1995;697:251-3

Lira A, Zhou M, Castanon N, Ansorge MS, Gordon JA, Francis JH, Bradley-Moore M, Lira J, Underwood MD, Arango V, Kung HF, Hofer MA, Hen R, Gingrich JA. Altered depression-related behaviors and functional changes in the dorsal raphe nucleus of serotonin transporter-deficient mice. Biol Psychiatry 2003;54:960-71

Maes M, Meltzer HYM. The serotonin hypothesis of major depression. In Psychopharmacology: The Fourth Generation of Progress. (Bloom F, Kupher D, eds), 1995, 933-944, Raven Press, New York, NY

Maffei M, Halaas J, Ravussin E, Pratley RE, Lee GH, Zhang $Y$, Fei $H$, Kim S, Lallone R, Ranganathan S, Kern PA, Friedman JM. Leptin levels in human and rodent: Measurement of plasma leptin and ob RNA in obese and weightreduced subjects. Nat Med 1995;1:1155-61 
Mann JJ. Role of the serotonergic system in the pathogenesis of major depression and suicidal behavior. Neuropsychopharmacology 1999;21:S99-S105

McCarthy DO, Daun JM. The effects of cyclooxygenase inhibits on tumor-induced anorexia in rats. Cancer 1993;71: 486-92
Paxinos G, Watson $C$. The rat brain in stereotaxic coordinate. 1986, Academic Press

Yamada J, Sugimoto $Y$, Hirose $H$, Kajiwara $Y$. Role of serotonergic mechanisms in leptin-induced suppression of milk intake in mice. Neurosci Lett 2003;348:195-7 